\title{
Lethal interactions among vertebrate top predators: a review of concepts, assumptions and terminology
}

\author{
Rui Lourenço ${ }^{1, *}$, Vincenzo Penteriani ${ }^{2,3}$, João E. Rabaça ${ }^{1}$ and Erkki Korpimäki ${ }^{4}$ \\ ${ }^{1}$ Department of Biology, LabOr - Laboratory of Ornithology, Instituto de Ciências Agrárias e Ambientais Mediterrânicas, Universidade de \\ Évora-Núcleo da Mitra, Ap. 94, Évora 7002-554, Portugal \\ ${ }^{2}$ Department of Conservation Biology, Estación Biológica de Doñana, C.S.I.C., c/Americo Vespucio s/n, Seville 41092, Spain \\ ${ }^{3}$ Finnish Museum of Natural History, Zoological Museum, University of Helsinki, Helsinki FI-20014, Finland \\ ${ }^{4}$ Section of Ecology, Department of Biology, University of Turku, Turku 20014, Finland
}

\begin{abstract}
Lethal interactions among large vertebrate predators have long interested researchers because of ecological and conservation issues. Research focusing on lethal interactions among vertebrate top predators has used several terms with a broad sense, and also introduced new terminology. We analysed the published literature with reference to the main underlying concepts and the use of terminology and its ecological context. The most frequently used terms in the literature were 'predation', 'intraguild predation', 'interference competition', and 'interspecific killing'. Most studies presented evidence of the killing of the victim $(77 \%)$, but information regarding its consumption was not given in $48 \%$ of cases. More than half of the analysed studies $(56 \%)$ had no solid information on the degree of competition between interacting species. By reviewing definitions and their underlying assumptions, we demonstrate that lethal interactions among large vertebrate predators could be designated using four terms - 'predation', 'intraguild predation', 'interspecific competitive killing', and 'superpredation' - without the need to employ additional terminology that may increase confusion and misuse. For a correct framework of these lethal interactions it is critical to assess if the kill is consumed, if the victim is indeed a competitor of the killer, and if the prey is a high-order predator. However, these elements of the framework are simultaneously the most common constraints to studies of lethal interactions, since they often require a great effort to obtain. The proper use of terms and concepts is fundamental to understanding the causes behind lethal interactions and, ultimately, what is actually happening in these complex interactions.
\end{abstract}

Key words: guild, interference competition, interspecific competitive killing, intraguild predation, lethal interactions, mesopredator release, superpredation..

\section{CONTENTS}

I. Introduction

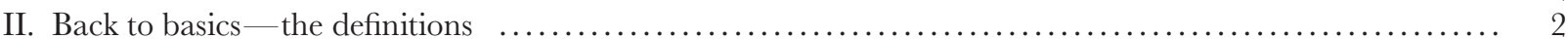

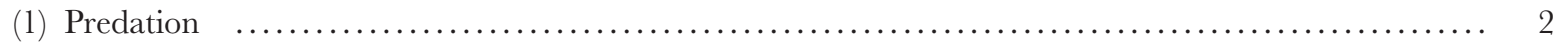

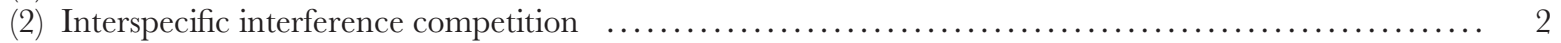

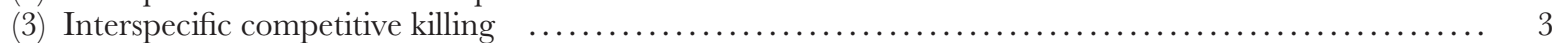

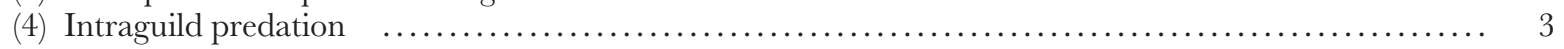

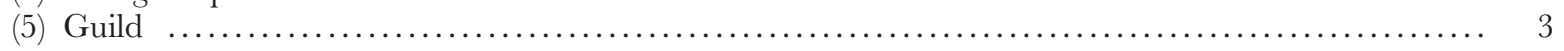

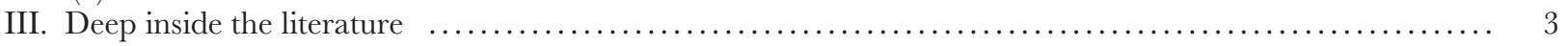

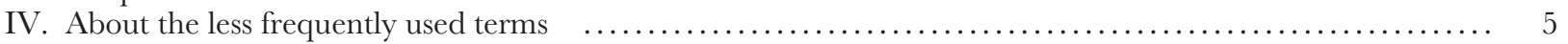

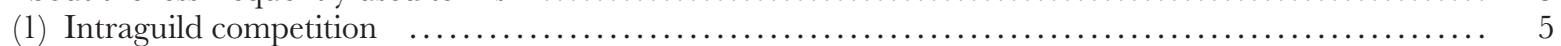

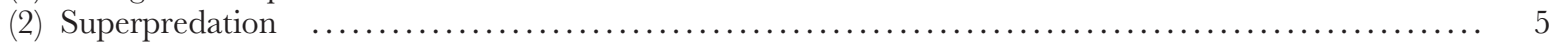

* Address for correspondence (E-mail: ruifazendalourenco@gmail.com). 


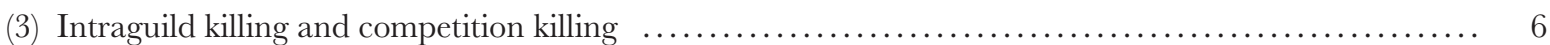

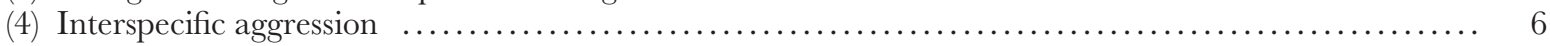

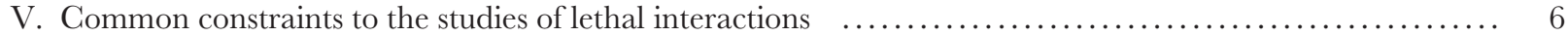

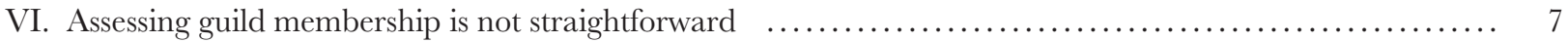

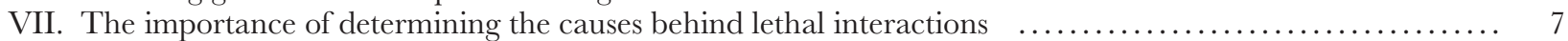

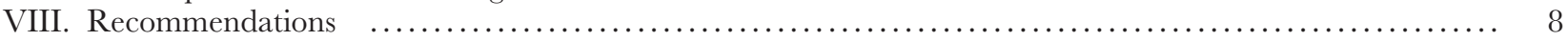

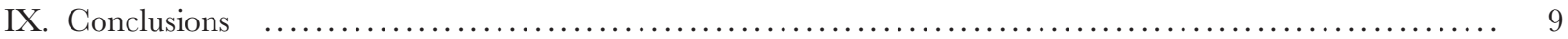

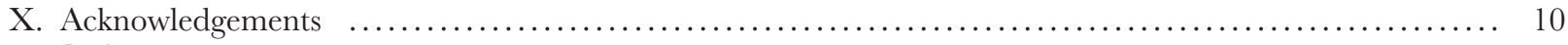

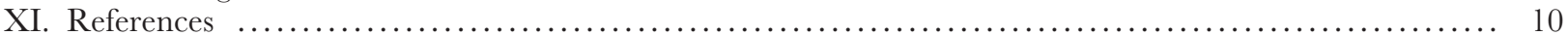

\section{INTRODUGTION}

Large vertebrate carnivorous species dominate the top of both terrestrial and marine food webs. These species are considered to be top predators, and generally have no or few species that prey on them. They occupy most ecosystems on Earth, from deserts to polar habitats, and many are charismatic species (e.g. large felids and canids, bears, large diurnal raptors and owls, crocodiles, large sharks, and killer whales). The interactions among top predators have always interested researchers, especially because of their ecological consequences on community structure, as well as their conservation and management implications (Schmitz, Hambäck \& Beckerman, 2000; Heithaus et al., 2008; Sergio et al., 2008). During the last two decades, there has been a substantial increase in the number of studies describing how vertebrate top predators can frequently engage in complex interspecific lethal and non-lethal interactions which can result from competition and predation (Polis, Myers \& Holt, 1989; Hakkarainen \& Korpimäki, 1996; Palomares \& Caro, 1999; Caro \& Stoner, 2003; Donadio \& Buskirk, 2006; Hunter \& Caro, 2008; Sergio \& Hiraldo, 2008). This has allowed a deeper understanding of these complex interactions, acknowledging that: (i) they are relatively common in nature (Palomares \& Caro, 1999; Arim \& Marquet, 2004; Sergio \& Hiraldo, 2008); (ii) most interactions are asymmetrical and size-based, and are often age-structured (Palomares \& Caro, 1999; Sergio \& Hiraldo, 2008); (iii) their frequency can be influenced by resource availability (Korpimäki \& Norrdahl, 1989a; Lourenço et al., $2011 b$ ); and (iv) the victims frequently display a behavioural response, which can sometimes be complex (Sergio \& Hiraldo, 2008; Ritchie \& Johnson, 2009).

We define here interspecific lethal interactions as the interactions between different species that end with one of the contenders being killed. Most frequently, these complex interactions have been described using four designations: (i) predation; (ii) intraguild predation; (iii) interference competition; and (iv) interspecific killing. These terms have associated definitions which are more or less well established. However, the increasing number of published articles has also led to the use of additional terms to define lethal interactions, and to a broader application of some of the above terms. The field of ecology has faced some criticism for using imprecise language and the misuse of concepts, which may lead to erroneous synonymy and redundancy
(Jaksić, 1981; Wilson, 1999; Driscoll \& Lindenmayer, 2012). Hence, clarifying ecological terminology is an essential basis to proper communication and a logical choice of framework, but also to ensure that the assumptions underlying concepts are correctly verified (Fauth et al., 1996; Scheiner, 2010; Driscoll \& Lindenmayer, 2012). The purpose of this paper is to clarify the use of terminology and thus facilitate to readers a better theoretical framework for their research on lethal interactions among vertebrate top predators. To accomplish this, we first review the definitions behind the most frequently used terms. Next, we review the literature and analyse how the terms have been used by researchers to describe lethal interactions among large vertebrate predators. We then discuss common constraints to studies of lethal interactions that influence the correct use of terminology. Finally, we suggest ways to improve the use of terminology and improve our understanding of these complex interspecific interactions.

\section{BACK TO BASICS - THE DEFINITIONS}

The complexity of lethal interactions and the large number of studies has led to considerable variation in their context and how terms have been applied, but also to the introduction of additional terms by some authors. Some lethal interactions among vertebrate top predators can be designated using more than one term, but although there may be some degree of overlap, the terms used are far from being synonyms. Thus, it is useful to always bear in mind their definitions.

\section{(1) Predation}

This concept is one of the pillars of ecology, and for the purposes of this article we simply need to stress that: $(i)$ this is a trophic interaction in which one organism (predator) consumes another (prey) as a source of energy (food), and (ii) in large vertebrate predators this interaction almost always implies the death of the prey.

\section{(2) Interspecific interference competition}

This interaction occurs when an individual from one species uses different types of mechanisms (non-trophic: e.g. chemicals, aggression, kleptoparasitism; trophic: adult, immature or egg predation) to exclude a resource from a competitor belonging to a different species (Case \& Gilpin, 
1974; Schoener, 1983). Interference competition may be mutual or unilateral (i.e. one species is dominant while the other is subordinate; Case \& Gilpin, 1974), with larger animals most frequently dominating smaller ones (Persson, 1985). Some cases of mutual interference competition are age dependent, i.e. species $\mathrm{A}$ is subordinate to species $\mathrm{B}$ when young but dominant when adult. We stress that the term 'interspecific interference competition' per se does not mean that the subordinate species is killed.

\section{(3) Interspecific competitive killing}

In large vertebrate predators, their weaponry can easily lead to the emergence of lethal forms of interspecific interference competition (Donadio \& Buskirk, 2006). Despite most studies simply use the term 'interspecific killing' (e.g. Palomares \& Caro, 1999; Glen \& Dickman, 2005; Donadio \& Buskirk, 2006; Hunter \& Caro, 2008; Ritchie \& Johnson, 2009), we prefer to designate these interactions as interspecific competitive killing because it implicitly includes the framework of competition associated with the act of killing. We found no formal definition associated with the terms 'interspecific competitive killing' and 'interspecific killing', but to separate these from intraguild predation, we consider it as an extreme form of interference competition in which a species kills a competitor without consuming it (or having the intention to use it as a food resource). However, it is fundamental to stress that the use of the term 'interspecific killing' to describe lethal interactions among top vertebrate predators has not been restricted to the above description, especially regarding the consumption of the victim. In fact, interspecific killing has been frequently assumed as a synonym of intraguild predation (Palomares \& Caro, 1999; Caro \& Stoner, 2003; Donadio \& Buskirk, 2006).

\section{(4) Intraguild predation}

This term was first used and defined by Polis \& McCormick (1986, 1987), but established mostly by the work of Polis et al. (1989) as a combination of competition and predation, where a species kills and eats another that is a potential competitor. Intraguild predation has also been considered as a special case of food-chain omnivory (the feeding by one species on resources at different trophic levels; see Pimm \& Lawton, 1978) or food-web omnivory (Aunapuu et al., 2010), but with the singularity that the predator and prey share a resource (Polis \& Holt, 1992). Other recognised synonyms of intraguild predation are predation interference or predatory interference, and predatory aggression (Case \& Gilpin, 1974; Polis et al., 1989).

\section{(5) Guild}

A crucial element intrinsic to the definition of intraguild predation is the concept of guild, first defined by Root (1967) as a group of species exploiting resources in a similar way, without any reference to the taxonomic position of the organisms involved. By adding that the limits of guild membership should be somewhat arbitrary, Root (1967) induced some of the existing flexibility of the term 'guild' used in subsequent studies (Hawkins \& MacMahon, 1989; Simberloff \& Dayan, 1991). Since then, the most common meaning for guild has been that of species sharing the same food resource (Simberloff \& Dayan, 1991). In the context of intraguild predation, Polis et al. (1989) suggested the use of the term 'guild' in a broader sense than that proposed by Root (1967), to include all taxa competing for resources, regardless of the tactics used. This use fits the widespread idea that guilds are 'arenas of intense interspecific competition' (Hawkins \& MacMahon, 1989).

\section{DEEP INSIDE THE LITERATURE}

We searched the Zoological Record (Web of Knowledge, Thomson Reuters; all records available from 1864 to August 2012) to find scientific articles that used the terms 'predation', 'interference competition', 'interspecific killing', 'intraguild predation', 'superpredator' and 'superpredation' to describe lethal interactions among vertebrate top predators. We combined these terms with each of the vertebrate top predator taxonomic groups considered (see Table 1). We also refined the searches using the term 'predation' by crossing the results obtained for mammalian carnivores and birds of prey with the other taxonomic groups. Additionally, we analysed in detail the references cited in these studies, especially the review papers, and used other publication search engines (Google Scholar, SciVerse Scopus), so that we could gather a larger number of studies.

We included in our database all articles that we could access and that specifically addressed lethal interactions among species belonging to mammalian carnivores (order Carnivora), cetaceans (order Cetacea), diurnal raptors (order Falconiformes), owls (order Strigiformes), crocodiles (order Crocodylia), monitor lizards (order Squamata, family Varanidae), and sharks, skates and rays (subclass Elasmobranchii). We also included articles in which the killer belonged to any of the previous species and the victim not, but the interaction was referred to as intraguild predation, interference competition, or interspecific killing. Each paper was thoroughly analysed to extract the information characterising the manuscript; to analyse the terminology used when mentioning the lethal interactions among the vertebrate top predator species involved; and to verify the reference to killing evidence, victim consumption, and competition evidence between the contenders.

We analysed 200 published papers (identified with asterisks in the reference list). From each publication we extracted the following information characterising the studies. (A) We subdivided the publications in two main groups: (i) original reports of lethal interactions between one or a few pairs of species of vertebrate top predators, or comments on these reports $(\mathcal{N}=187)$; and (ii) those compiling and reviewing lethal interactions among a group of vertebrate top 
Table 1. Number of scientific articles obtained from a search of publications in the Zoological Record (Web of Knowledge, Thomson Reuters; all records available from 1864 to August 2012) combining the terms (search as 'topic')

\begin{tabular}{|c|c|c|c|c|c|c|}
\hline & Predation & Interference competition & Interspecific killing & Intraguild predation & Superpredator & Superpredation \\
\hline Garnivore & 4644 & 84 & 91 & 48 & 6 & 0 \\
\hline Carnivora & 4375 & 77 & 86 & 42 & 6 & 0 \\
\hline Cetacea & 350 & 5 & 2 & 0 & 0 & 0 \\
\hline Whale & 271 & 3 & 1 & 0 & 0 & 0 \\
\hline Dolphin & 95 & 2 & 2 & 0 & 0 & 0 \\
\hline Raptor & 461 & 13 & 7 & 6 & 1 & 1 \\
\hline Owl & 809 & 9 & 11 & 12 & 1 & 2 \\
\hline Birds of prey & 7744 & 84 & 33 & 23 & 5 & 2 \\
\hline Reptile & 3423 & 32 & 6 & 10 & 0 & 0 \\
\hline Shark & 267 & 1 & 0 & 1 & 0 & 0 \\
\hline
\end{tabular}

predators $(\mathcal{N}=13)$. (B) We considered the focus of the study, separating publications based on $(i)$ those reporting killing or predation events (direct observation, finding a killed animal, remains identified in diet analysis of scats, pellets or other prey remains; $\mathcal{N}=66$ ); (ii) those reporting numerical or behavioural effects related to the presence or absence of the risk of being killed and/or preyed on by another species, often associated with the mesopredator release/suppression hypothesis and trophic cascades $(\mathcal{N}=105)$; (iii) those analysing the potential for competition, predation or killing among species $(\mathcal{N}=16)$; and $(i v)$ those that did not fit into any of the above classifications $(\mathcal{N}=13)$. (C) The taxonomic group of the killer/dominant species was: mammalian carnivores $(57 \% ; \mathcal{N}=113$ studies); diurnal raptors and owls $(31 \% ; \mathcal{N}=62$ studies $)$; cetaceans $(7 \% ; \mathcal{N}=14$ studies $)$; several groups $(3 \% ; \mathcal{N}=6$ studies $) ;$ sharks $(3 \%, \mathcal{N}=5$ studies). We obtained no studies reporting lethal interactions among vertebrate top predators with large predatory reptiles as killers. (D) Taxonomic restriction of the killer(s) and vic$\operatorname{tim}(\mathrm{s})$, i.e. if they belong to the same order $(\mathcal{N}=131$ studies; representing $66 \%)$ and the same family $(\mathcal{N}=61$ studies; representing 31\%). (E) Date of publication, which showed how the number of studies has been increasing over the last decades (Fig. 1).

Frequently, more than one term was used in the same publication to designate the lethal interaction in question. Predation was the most commonly used, being employed in $78 \%$ of studies $(\mathcal{N}=156)$. Intraguild predation was used in $46 \%(\mathcal{N}=92)$, while interference competition was used in $34 \%$ of studies $(\mathcal{N}=67)$. Interspecific killing was the fourth most common term used, employed in $12 \%$ of studies $(\mathcal{N}=23)$. Among the terms used less frequently were: intraguild competition $(\mathcal{N}=12)$; superpredation $(\mathcal{N}=5$; the term superpredator was used in five other studies); intraguild killing $(\mathcal{N}=5)$; interspecific aggression $(\mathcal{N}=3)$; competitive killing $(\mathcal{N}=1)$; competition killing $(\mathcal{N}=1)$; intracarnivore predation $(\mathcal{N}=1)$; and omnivory $(\mathcal{N}=1)$.

Presenting killing evidence is a key element in potentially lethal interactions, especially to allow separation between (i) the effects of the risk of being killed, and (ii) the risk of suffering non-lethal mechanisms of interference from a dominant competitor. This is particularly relevant for

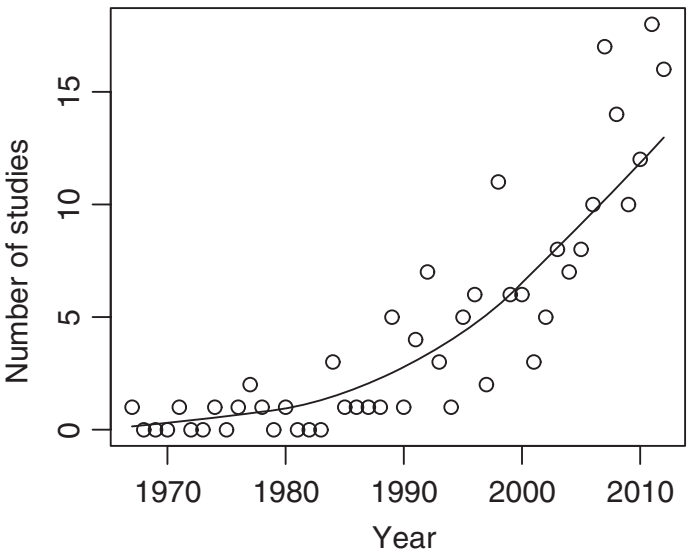

Fig. 1. Number of studies per year reporting lethal interactions among vertebrate top predators, fitted with a local polynomial regression smooth curve.

studies reporting the numerical and behavioural effects of risk $(\mathcal{N}=105)$. Considering all studies, we found that the majority $(77 \%, \mathcal{N}=154)$ presented the authors' own data of killing acts or were supported by bibliographic references reporting these events (Fig. 2A).

Almost half of the studies $(48 \% ; \mathcal{N}=95)$ gave no information regarding the consumption of the victim. Consumption was verified in $39 \%$ of the studies $(\mathcal{N}=78)$, and in $6 \%(\mathcal{N}=11)$ consumption was only partial or did not always occur (Fig. 2B). Fifteen studies reported the killing but no consumption of the victim (8\%). Only $41 \%$ of studies using the term 'intraguild predation' reported the consumption of the victim by the predator (38 out of 92 studies).

From all the studies, 35\% presented evidence of potentially moderate to strong competition among killers and victims $(\mathcal{N}=69)$, while $56 \%$ had no information on this aspect $(\mathcal{N}=112$; Fig. 2C). Only $7 \%$ reported that there was no competition among killer and victim $(\mathcal{N}=13)$, while $3 \%$ mentioned that the degree of competition was weak $(\mathcal{N}=6)$. From the 92 studies using the term 'intraguild predation', only $49 \%(\mathcal{N}=45)$ mentioned that killer and victim were in fact moderate to strong competitors. 

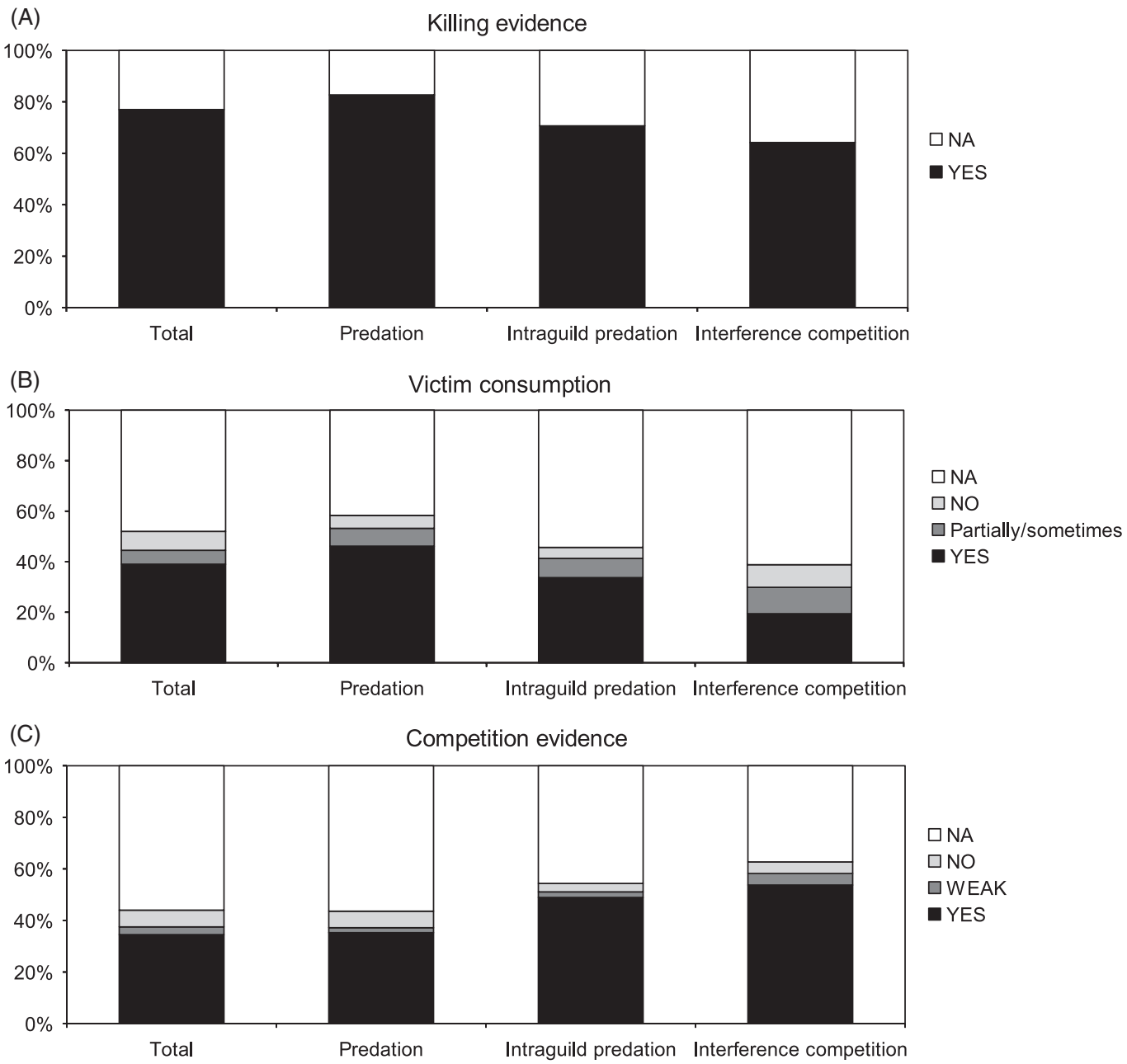

Fig. 2. Percentage of studies using the terms 'predation', 'intraguild predation', and 'interference competition' that present evidence of: (A) killing of the victim; (B) consumption of the victim; and (C) the degree of competition between killer and victim. NA, information not presented in the paper.

\section{ABOUT THE LESS FREQUENTLY USED TERMS}

\section{(1) Intraguild competition}

The use of this term was not frequent or consistent in the articles analysed, being employed together with the more common terminology. Intraguild competition is basically a synonym of interspecific competition. Moreover, considering the above-mentioned concept of guild, the term 'intraguild competition' somewhat represents the redundancy 'competition among competitors'. This term has more frequently been used as a synonym of interspecific interference competition, and it was often associated with the use of guild as a group of species, usually taxonomically related, as for example a 'carnivore guild' (Vanak, Thaker \& Gompper, 2009; Vanak \& Gompper, 2010; Davis, Kelly \& Stauffer, 2011). The expression 'competitive intraguild interactions' has been used to include interference competition and intraguild predation (St-Pierre, Ouellet \& Crête, 2006). Considering the other existing terms, we do not find intraguild competition particularly useful in this context, having the possible inconvenience of generating more confusion.

\section{(2) Superpredation}

This term has seldom and only relatively recently been used in scientific publications focusing on lethal interactions among vertebrate predators. It is not well established and its definition does not seem very straightforward. In ecology, the terms 'top predator', 'top-order predator', 'alpha predator', and 'apex predator' are used as synonyms, to designate species at the top (or very near the top) of a food chain, generally above trophic level 3 or 4 (secondary or tertiary consumers), and that are not preyed upon by any other animal (Fretwell, 1987; Estes, Crooks \& Holt, 2001; Pimm, 2002; Essington, Beaudreau \& Wiedenmann, 2006; Sergio et al., 2008; Hayward \& Somers, 2009; Prugh et al., 2009). The term 'superpredator' is rather common in scientific literature (e.g. Smouse, 1981; Rinaldi \& Muratori, 1992; Compagno, Marks \& Fergusson, 
1997; De Feo \& Rinaldi, 1997; Bosch et al., 2007; Berryman \& Kindlmann, 2008; Chakarov \& Krüger, 2010; Davis et al., 2011), mostly applied with a similar meaning as top predator, and often defined simply as a predator that eats other predators (Courchamp, Langlais \& Sugihara, 1999; Moleón \& Gil-Sánchez, 2003; Russel et al., 2009). However, to the best of our knowledge, there is no formal definition for superpredation. Southern (1947) used superpredation to address the killing of sparrowhawks Accipiter nisus by goshawks Accipiter gentilis. Fauth (1990) used superpredation with the meaning of '.. . predators eating other predators...' in a freshwater food web involving amphibians and crayfish. Ruiz-Olmo \& Marsol (2002) reported the predation of fish-eating birds by otters Lutra lutra and defined superpredation as '... one predator killing competing predators, which may contribute to their regulation and thereby to the conservation or increase in the stock of available prey'. Tannerfeldt, Elmhagen \& Angerbjörn (2002) used superpredation as a synonym of intraguild predation by red fox Vulpes vulpes on arctic fox Alopex lagopus. Malo et al. (2004) used superpredation referring to wildcats Felis silvestris preying on other mammalian carnivore species. More recently, Lourenço et al. $(2011 b, c)$ used the term 'superpredation' to include all acts of predation by four large birds of prey on mammalian carnivores, diurnal raptors and owls, independently of predator and prey being competitors; simplifying it as 'predation on other top predators'. Considering the above, here we define superpredation as 'the act performed by top predators of killing and consuming highorder predators (either top predators or meso-predators), independently of the degree of sharing of resources, and thus independently as well of their status as competitors'. In addition, these prey species (high-order predators) should belong at least to trophic level 3 (secondary consumers/primary carnivores), and generally should not represent the main prey of the superpredator. Therefore, superpredation only occurs at the top end of food chains, which means that superpredators might be at trophic level 4 in short food chains and reach up to trophic level 5 or more in long food chains (Post, 2002; Essington et al., 2006). This term may sometimes be useful to describe lethal interactions among vertebrate top predators, as discussed more thoroughly below.

\section{(3) Intraguild killing and competition killing}

Intraguild killing and competition killing are basically synonyms of interspecific competitive killing. Since these are not frequently used and thus not well-established among researchers, we suggest that preference should be given to the use of interspecific competitive killing, or its shorter form, interspecific killing.

\section{(4) Interspecific aggression}

Interspecific aggression has limited use in lethal interactions, because it gives no information on the effective killing of the victim of aggression, or its additional consumption.

\section{GOMMON GONSTRAINTS TO THE STUDIES OF LETHAL INTERAGTIONS}

Taxonomic restriction is a common feature in the studies of lethal interactions; we found that $66 \%$ of the analysed papers reported events between species belonging to the same order. This may be because species belonging to the same taxonomic group are more similar and thus more prone to competition and consequent lethal interactions. But since competition is generally not restricted to members of the same taxon (order, family, or genus), we should also consider more practical reasons, such as the researchers' expertise and focus on a single group of animals (e.g. mammalian carnivores, diurnal raptors, owls).

Determining if the subordinate species was in fact killed or just harassed is a key point in separating lethal from nonlethal interactions. We found that the majority of studies presented killing evidence of the victim, however about onethird of the studies using the term 'intraguild predation' did not completely confirm the lethality of the interaction between the dominant and subordinate species (Fig. 2A).

The consumption of the killed victim, even if partial, determines if the interaction is predatory or exclusively competitive (Sunde, Overskaug \& Kvam, 1999). More than half of the studies using the term 'intraguild predation' did not give information about the consumption of the supposed intraguild prey (Fig. 2B).

The greatest constraint is perhaps to determine if predator and prey are competitors, i.e. if they belong to the same guild, in order to designate the interaction as intraguild predation. Competition between killer and victim was only confirmed in 35\% of all studies and in $49 \%$ of studies using the term 'intraguild predation'. Verifying interspecific competition in nature is one of the hardest tasks researchers in this field face, and is prone to a considerable amount of subjectivity (Mac Nally, 1983; Schoener, 1983; see Section VI). This task is even harder when dealing with vertebrate top predators, which often have large home ranges, and also raise ethical constraints to manipulations. One way to assess competition among vertebrate top predators can be, for example, by observing differences in dietary overlap and reproductive success between neighbouring and nonneighbouring pairs of two predator species (Korpimäki, 1987). Other useful experimental approaches include the manipulation of artificial breeding sites (Hakkarainen \& Korpimäki, 1996), and the display of dummies and playbacks of a potential competitor and/or predator (Krüger, 2002).

The mesopredator release hypothesis, coined by Soulé et al. (1988), has been frequently linked to intraguild predation between top predators and mesopredators (Gehrt \& Clark, 2003; Gehrt \& Prange, 2007; Salo et al., 2008; Letnic, Crowther \& Koch, 2009; Prugh et al., 2009; Ritchie \& Johnson, 2009; Roemer, Gompper \& Van Valkenburgh, 2009; Elmhagen et al., 2010; Letnic \& Dworjanyn, 2011). However it is crucial to stress that the phenomena of mesopredator release and suppression can sometimes be independent of intraguild predation, namely in two ways. 
Firstly, when the predatory interaction occurs between a mesopredator that is not a competitor of the top predator, e.g. killer whales and sea otters (Estes et al., 1998). Second, when the phenomenon of release or suppression of a mesopredator is caused by interference competition (including killing) without the mesopredator being consumed by the top predator (e.g. skunks and coyotes: Prange \& Gehrt, 2007). Contrary to what has been frequently written, the mesopredator release hypothesis, as first described by Soulé et al. (1988; see also Crooks \& Soulé, 1999; Glen \& Dickman, 2005), does not implicitly include the existence of competition between top predator and mesopredators (respectively coyotes, and foxes, cats, raccoons, skunks, opossums in Soulé et al., 1988). An analysis of the 33 papers included in our study and that were among the 73 described cases of mesopredator release reviewed by Ritchie \& Johnson (2009), showed that in $9 \%(\mathcal{N}=3)$ there was no consumption of the victim and in $45 \%(\mathcal{N}=15)$ there was no information on its consumption. Moreover, in these 33 cases, $6 \%(\mathcal{N}=2)$ mentioned that killer and victim were not competitors, while $64 \%(\mathcal{N}=21)$ gave no information about potential competition between top predators and mesopredators. So, before bringing together the phenomena of mesopredator release/suppression and intraguild predation it is fundamental to have a solid knowledge of the nature of the interaction between the top predator and mesopredator.

\section{ASSESSING GUILD MEMBERSHIP IS NOT STRAIGHTFORWARD}

Most studies attempting to define the structure of vertebrate guilds have only focused on well-defined taxonomic and spatially restricted groups of species; moreover, many of these studies frequently only use food-niche overlap to define trophic guilds (Herrera \& Hiraldo, 1976; Pianka, 1980; Jaksić, 1988; Marti, Korpimäki \& Jaksić, 1993; Muñoz \& Ojeda, 1998; Zapata et al., 2007), missing other possible shared resources (e.g. roosting and breeding sites) for which species might compete. However, defining a guild structure accurately is a demanding task, which requires detailed information on the life history of many species (Pianka, 1980; Mac Nally, 1983; Hawkins \& MacMahon, 1989; Simberloff \& Dayan, 1991; Blondel, 2003). Despite the existence of many quantitative methods for guild assignment, there is always some ambiguity because the level of clustering is set arbitrarily by the researcher (Jaksić, 1988; Simberloff \& Dayan, 1991; Mac Nally et al., 2008).

Local conditions may introduce spatial variations in guild structures, i.e. the same group of species may or may not compete depending on the ecological scenario in which they are interacting (Herrera \& Hiraldo, 1976; Jaksić, 1988; Hawkins \& MacMahon, 1989). This inconsistency can be illustrated by the predation by eagle owls Bubo bubo on barn owls Tyto alba (Lourenço et al., 2011b) throughout most of Europe, two predators with very short diet overlap in the Iberian Peninsula, but considerable food overlap in Central Europe (Herrera \& Hiraldo, 1976). Accordingly, this interaction could be named intraguild predation in Central Europe but not in the Iberian Peninsula. In addition, guilds may also show temporal variations resulting from changes in resource availability with time, as for example among seasons (Hawkins \& MacMahon, 1989) and years (Korpimäki, 1987). All these constraints in defining guild and assessing competition seem to concur with most studies of intraguild predation among large vertebrate predators involving just a few species (generally two or three), and lacking information about the degree of competition. Consequently, intraguild predation at a broader community scale has very seldom been analysed.

The assignment of guild membership, crucial to the intraguild predation concept, is not as straightforward as we would desire. Then, how do we name those interactions in which both predator and consumed prey are high-order predators but competition does not occur or could not be verified? These could simply be named predation, but if researchers are interested in highlighting them from more conventional acts of predation, then superpredation can be an alternative term.

\section{THE IMPORTANGE OF DETERMINING THE GAUSES BEHIND LETHAL INTERAGTIONS}

Considering the above, and in order to provide a solid framework and an adequate application of terminology, it is useful to know the evolutionary explanations behind lethal interactions. This rationale is also important when dealing with species of conservation concern, as is the case for many species of large vertebrate predators. Several studies have already debated the possible causes behind lethal interactions among vertebrate top predators (Palomares \& Caro, 1999; Donadio \& Buskirk, 2006; Sergio \& Hiraldo, 2008; Lourenço et al., $2011 a, b)$, but none has tried to link these causes with the end result of the interactions, and the terms used to designate these interactions.

(1) The most frequently considered explanation is active food acquisition, which is frequently related to food-stress situations (Korpimäki \& Norrdahl, 1989a; Rohner \& Doyle, 1992; Tella \& Mañosa, 1993; Serrano, 2000; Lourenço et al., 2011 b). When facing a decrease in the availability of the main prey, the top predator will actively search for alternative prey, which can sometimes belong to higher trophic levels, and that may require different hunting techniques and greater risk to the predator (food-stress hypothesis). In these cases, the victim should be totally or almost totally consumed, and there should not be discrimination between competitor and non-competitor mesopredators (Sunde et al., 1999; Serrano, 2000).

(2) Some top predators have an overwhelming superiority compared to other competitors, resulting from their greater size or weaponry, and may simply predate these species based 
on opportunism, without being in a food-stress situation. In this case, guild-prey should be a regular component of the diet of the predator through time.

(3) Another suggested cause is killing a competitor to free resources (Polis et al., 1989; Palomares \& Caro, 1999; Sunde et al., 1999). This explanation has been related to the fact that sometimes the victim is not consumed or partially eaten (Boyd \& Neale, 1992; Sunde et al., 1999; Helldin, Liberg \& Glöersen, 2006). The competitor-removal hypothesis implies that the killer perceives the victim as a competitor and deliberately eliminates it, which in some cases is in order to obtain an indirect and non-immediate benefit (e.g. liberate food resources). If removing a competitor requires an active search, then the killer should have a clear perception of the derived benefit. This hypothesis seems more plausible in cases where the killer obtains an immediate benefit, such as the removal of a competitor to make an occupied breeding site available.

(4) Eliminating a threat (potential killer, predator or very aggressive mobber) to the individual or its offspring may also cause lethal interactions among large vertebrate predators (Klem, Hillegrass \& Peters, 1985; George, 1989; Palomares \& Caro, 1999; Mateo \& Olea, 2007; Lourenço et al., 2011 a; Kamler et al., 2012). Aggressive interactions between large vertebrate species have been reported frequently in the literature, and the perception of a threatening individual seems much more likely than the perception of a competitor, supporting this explanation (Zuberogoitia et al., 2008a; Lourenço et al., 2011a).

(5) In lethal interactions between dolphins and porpoises other causes have been suggested such as fight practising, sexual frustration, and equivocated conspecific infanticide (Ross \& Wilson, 1996; Patterson et al., 1998).

It is essential to stress that some lethal interactions among large vertebrate predators probably result from different combinations of these triggers, with each event representing a complex trade-off of risks and benefits of attacking a top predator, assessed on a short-term basis.

We consider that in interspecific competitive killing events the main cause should be removing a competitor or potential predator, and generally no consumption of the kill is involved. In intraguild predation events the possible explanations are obtaining food and/or removing a competitor or potential predator. This interaction may begin as an episode of interspecific competitive killing, and then the killer takes advantage of an available food source by consuming it. An alternative perspective of intraguild predation events is the situation of the killer being in food stress and using a competitor, that usually is not prey, as a food resource. Above all, intraguild predation may be a complex combination of the will to remove a predator/competitor and to obtain food, which renders more benefits to the intraguild predator than simply killing the competitor or capturing an alternative non-guild prey. In the most generic cases of superpredation the main cause should be obtaining food, facilitated by the dominance of a superpredator which can subdue other top predators, and thus represents a case of omnivory at the top of the food chain.

\section{RECOMMENDATIONS}

We suggest that the terms 'interspecific competitive killing', 'intraguild predation' and 'superpredation' can be applied to designate lethal interactions among vertebrate predators without the need to introduce additional terminology. But, despite some similarities, these three terms do not overlap completely in their meanings. Thus, in our opinion it is crucial to stress the differences and similarities between them, aiming to achieve a better use of these and other terms, as well as the underlying concepts, when studying interactions among vertebrate predators (Fig. 3).

(1) Consumption of the kill. The concept of interspecific competitive killing does not specify if the victim is consumed or not, while intraguild predation and superpredation always implicitly include the consumption of the victim, even if partial. Therefore, intraguild predation and superpredation should not be applied when the victim is not consumed. The intraguild predation concept includes all cases of interspecific competitive killing where consumption occurs.

(2) Killing a competitor. Both intraguild predation and interspecific competitive killing imply that the victim is a competitor, while superpredation also includes predation on other high-order predators which are not competitors. Superpredation among competitors should preferably be named intraguild predation.

(3) Preying on a high-order predator. Superpredation could be used for all cases of intraguild predation involving high-order predators, although it is not restricted to them. We stress that the intraguild predation concept also includes predation among competitors which are not top predators (e.g. a secondary consumer that eats a primary consumer - herbivore - with which it shares a resource).

In summary, we suggest using intraguild predation every time consumption and competition is confirmed, since this term is more informative than predation, interspecific competitive killing, or superpredation. Interspecific competitive killing should then be used when no consumption of the killed competitor occurs or the consumption cannot be confirmed. Superpredation should be used when the victim is consumed but the killer and victim are not competitors or competition cannot be determined, and additionally where there is interest in separating this interaction among high-order predators from acts of predation on the main prey.

Finally, non-lethal interactions, such as interspecific aggression, may produce effects on the subordinate species similar to those of lethal interactions. If the only information available is the non-lethal effects of an interaction, then one cannot determine fully the nature of that interaction. Therefore, when there is no information on the killing and consumption of a subordinate species being affected 


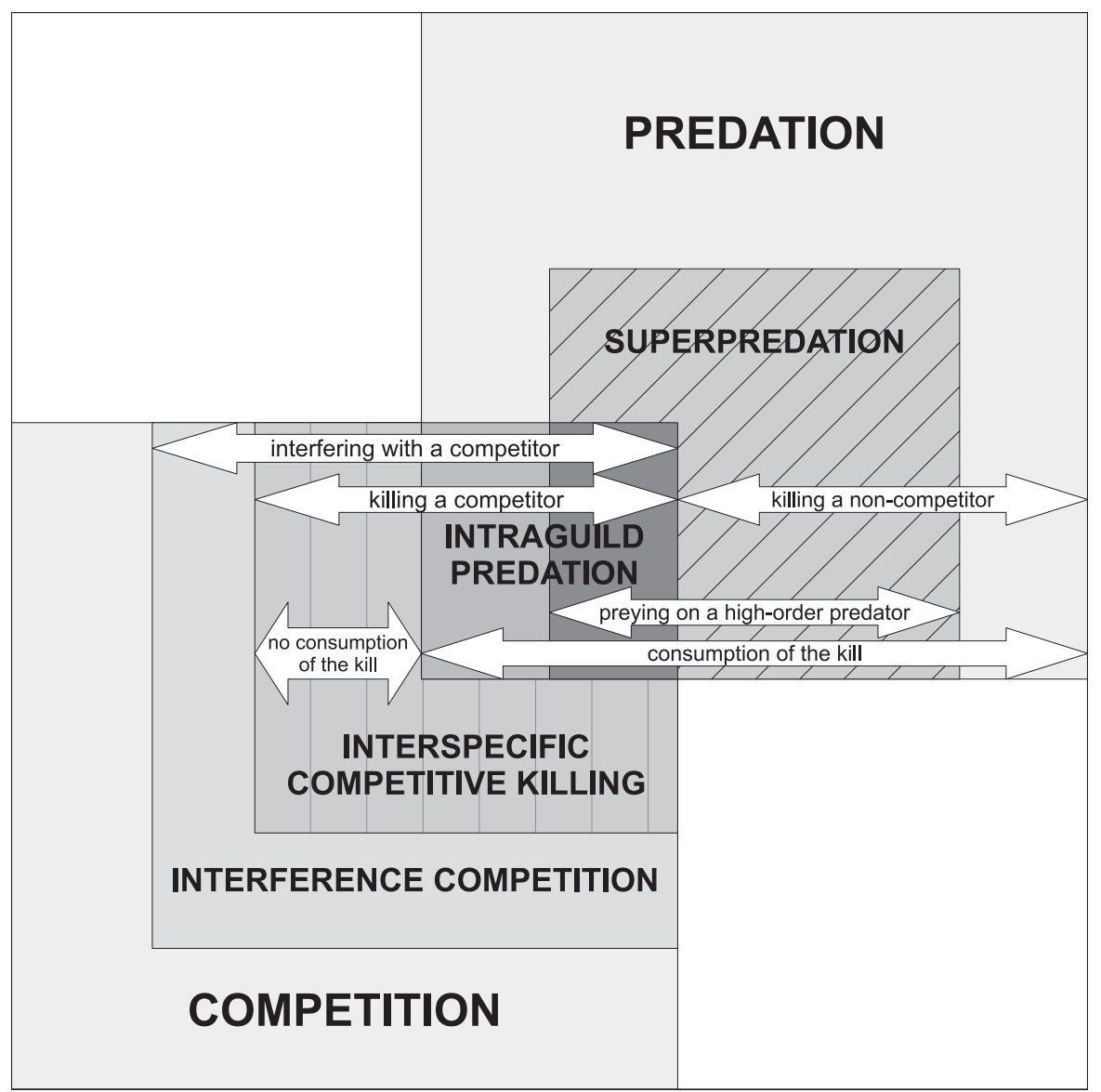

Fig. 3. Illustration of the differences, similarities and overlaps in terminology used in lethal interspecific interactions among vertebrate top predators. Intraguild predation is an overlap of predation and competition, implicitly including the consumption of the killed competitor. Intraguild predation overlaps with superpredation (dark grey) when the intraguild prey is a high-order predator; whereas the interactions falls out superpredation (intermediate grey) when the intraguild prey is not a high-order predator. Superpredation (diagonal stripes) is a special case of predation, where the prey is a high-order predator which is always consumed. Superpredation overlaps with intraguild predation (dark grey area) when the prey, besides being a high-order predator, is also a competitor. Interspecific competitive killing overlaps with intraguild predation when the victim is consumed (intermediate grey area) and overlaps with both intraguild predation and superpredation when the consumed victim is a high-order predator (dark grey area). When a competitor is killed but not consumed then it only falls within the concept of interspecific competitive killing and not in the concepts of intraguild predation or superpredation. Below we give examples of vertebrate species illustrating these types of interactions. Predation: an eagle owl Bubo bubo kills and consumes a rabbit Oryctolagus cuniculus. Superpredation but not intraguild predation: an eagle owl kills and consumes a barn owl Tyto alba, a high-order predator but not a strong competitor. Intraguild predation and superpredation: an eagle owl kills and consumes a common buzzard Buteo buteo, a high-order predator and a competitor. Intraguild predation but not superpredation: a great tit Parus major kills and eats a bat, with which it competes for tree holes. Interspecific competitive killing (but not intraguild predation or superpredation): a Eurasian lynx Lynx lynx kills a fox but does not consume it. Interference competition (without killing): a goshawk Accipiter gentilis displaces a common buzzard from its nest site. Competition (exploitation): Iberian lynx Lynx pardinus and eagle owls compete for rabbits as a food resource.

by an aggressive dominant competitor, the most correct term to designate this interaction is 'interspecific interference competition'.

\section{GONGLUSIONS}

(1) Studies reporting lethal interactions among vertebrate top predators frequently do not mention if the victim is consumed, and if the victim and killer are in fact competitors, hindering the understanding of the ecological context of these events.

(2) The terms 'interspecific competitive killing', 'intraguild predation' and 'superpredation' can be applied to designate lethal interactions among vertebrate predators without the need to introduce additional terminology, which will mostly contribute to increasing confusion and misuse.

(3) The most common constraints to studies on lethal interactions are: (i) their taxonomic restriction; (ii) confirming that killing really occurs; (iii) verifying if the victim is 
consumed; and ( $i v)$ determining the degree of competition between the killer and victim, i.e. if they belong to the same guild. In addition, mesopredator release phenomena and intraguild predation have been linked without sufficient evidence.

(4) Before deciding which is the most adequate term and concept to apply to a particular scenario of lethal interactions among large vertebrate predators, we should ask ourselves three preliminary questions: (i) was the victim consumed; (ii) is the victim a competitor of the killer; (iii) is the victim a high-order predator?

(5) Adequate use of the terminology also depends on how well we understand the causes behind lethal interactions, which, besides correlative, requires future experimental studies. The most commonly suggested hypotheses are: (i) food stress; (ii) opportunistic diet; (iii) competitor removal; and (iv) predator removal.

\section{ACKNOWLEDGEMENTS}

We thank S.M. Santos and two anonymous reviewers for providing useful comments on a previous version of this manuscript. R.L. was supported by a post-doctoral degree grant (BPD/78241/2011) from FCT - Foundation for Science and Technology, Portugal. E.K. was supported by grants of the Academy of Finland (project no. 123379, 136717 and 250709).

\section{REFERENGES}

*Arim, M. \& Marquet, P. A. (2004). Intraguild predation: a widespread interaction related to species biology. Ecology Letters 7, 557-564.

*Aunapuu, M. \& Oksanen, T. (2003). Habitat selection of coexisting competitors: a study of small mustelids in northern Norway. Evolutionary Ecology 17, 371-392.

Aunapuu, M., Oksanen, T., Oksanen, L. \& Korpimäki, E. (2010). Intraguild predation and interspecific co-existence between predatory endotherms. Evolutionary Ecology Research 12, 151-168.

*Azevedo, F. C. C. \& Verdade, L. M. (2012). Predator-prey interactions: jaguar predation on caiman in a floodplain forest. Fournal of Zoology 286, 200-207.

*Bailey, E. P. (1992). Red foxes, Vulpes vulpes, as biological control agents for introduced arctic foxes, Alopex lagopus, on Alaskan Islands. Canadian Field-Naturalist 106, 200-205.

*Ballard, W. B. (1980). Brown bear kills gray wolf. Canadian Field-Naturalist 94, 91.

*Baucells, J. (2011). Brood defence by a female Long-eared Owl Asio otus against an attack by a Tawny Owl Strix aluco. Revista Catalana d'Ornitologia 27, 36-39.

*Berger, K. M. \& Conner, M. M. (2008). Recolonizing wolves and mesopredator suppression of coyotes: impacts on pronghorn population dynamics. Ecological Applications 18, 599-612.

*Berger, K. M. \& GESE, E. M. (2007). Does interference competition with wolves limit the distribution and abundance of coyotes? Fournal of Animal Ecology 76, 1075-1085.

*Berger, K. M., Gese, E. M. \& Berger, J. (2008). Indirect effects and traditional trophic cascades: a test involving wolves, coyotes, and pronghorn. Ecology 89, $818-828$.

Berryman, A. A. \& Kindlmann, P. (2008). Population Systems: A General Introduction. Springer, Dordrecht.

*Bider, J. R. \& Weil, P. G. (1984). Dog, Canis familiaris, killed by a coyote, Canis latrans, on Montreal Island, Quebec. Canadian Field-Naturalist 98, 498-499.

*Biggins, D. E., Hanebury, L. R., Miller, B. J. \& Powell, R. A. (2011). Black-footed ferrets and Siberian polecats as ecological surrogates and ecological equivalents. Fournal of Mammalogy 92, 710-720.

*Blanco, G., Traverso, J. M., Marchamalo, J. \& Martínez, F. (1997). Interspecific and intraspecific aggression among griffon and cinereous vultures at nesting and foraging sites. Fournal of Raptor Research 31, 77-79.
BlONDEL, J. (2003). Guilds or functional groups: does it matter? Oikos 100, 223-231. *Boles, B. K. (1977). Predation by wolves on wolverines. Canadian Field-Naturalist 91, 68-69.

*Bosch, R., Real, J., Tintó, A. \& Zozaya, E. L. (2007). An adult male Bonelli's Eagle (Hieraaetus fasciatus) eaten by a subadult Golden Eagle (Aquila chrysaetos). Fournal of Raptor Research 41, 338.

*Boveng, P. L., Hiruki, L. M., Schwartz, M. K. \& Bengtson, J. L. (1998). Population growth of antarctic fur seals: limitation by a top predator, the leopard seal? Ecology 79, 2863-2877.

*Boyd, D. K. \& Neale, G. K. (1992). An adult cougar, Felis concolor, killed by gray wolves, Canis lupus, in Glacier National Park, Montana. Canadian Field-Naturalist 106, $524-525$.

*Brambilla, M., Bassi, E., Ceci, C. \& Rubolini, D. (2010). Environmental factors affecting patterns of distribution and co-occurrence of two competing raptor species. Ibis 152, 310-322.

*Brambilla, M., Rubolini, D. \& Guidali, F. (2006). Eagle owl Bubo bubo proximity can lower productivity of cliff-nesting peregrines Falco peregrinus. Ornis Fennica 83 $20-26$.

*Brandt, M. J. \& Lambin, X. (2007). Movement patterns of a specialist predator, the weasel Mustela nivalis exploiting asynchronous cyclic field vole Microtus agrestis populations. Acta Theriologica 52, 13-25.

*Brawata, R. L. \& Neeman, T. (2011). Is water the key? Dingo management, intraguild interactions and predator distribution around water points in arid Australia. Wildlife Research 38, 426-436.

*Brook, L. A., Johnson, C. N. \& Ritchie, E. G. (2012). Effects of predator control on behaviour of an apex predator and indirect consequences for mesopredator suppression. Fournal of Applied Ecology 49, 1278-1286.

*Byholm, P., Burgas, D., Virtanen, T. \& Valkama, J. (2012). Competitive exclusion within the predator community influences the distribution of a threatened prey species. Ecology 93, 1802-1808.

*Byholm, P. \& Nikula, A. (2007). Nesting failure in Finnish northern goshawks Accipiter gentilis: incidence and cause. Ibis 149, 597-604.

*CARo, T. M. (1987). Cheetah mothers' vigilance: looking out for prey or for predators? Behavioral Ecology and Sociobiology 20,351-361.

*Caro, T. M. \& Stoner, C. J. (2003). The potential for interspecific competition among African carnivores. Biological Conservation 110, 67-75.

*Casanovas, J. G., Barrul, J., Mate, I., Zorrilla, J. M., Ruiz-Olmo, J., GosÀlbez, J. \& SAlicrú, M. (2012). Shaping carnivore communities by predator control: competitor release revisited. Ecological Research 27, 603-614.

CAse, T. J. \& Gilpin, M. E. (1974). Interference competition and niche theory. Proceedings of the National Academy of Sciences 71, 3073-3077.

*Chakarov, N. \& Krüger, O. (2010). Mesopredator release by an emergent superpredator: a natural experiment of predation in a three level guild. PLoS ONE 5(12), e15229.

Compagno, L. J. V., Marks, M. A. \& Fergusson, I. K. (1997). Threatened fishes of the world: Carcharodon carcharias (Linnaeus, 1758). Environmental Biology of Fishes 50, 61-62.

*Constantine, R., Visser, I., Buurman, D., Buurman, R. \& McFadden, B. (1998). Killer whale (Orcinus orca) predation on dusky dolphins (Lagenorhynchus obscurus) in Kaikoura, New Zealand. Marine Mammal Science 14, 324-330.

*Cotter, M. P., Maldini, D. \& Jefferson, T. A. (2011). "Porpicide" in California: killing of harbor porpoises (Phocoena phocoena) by coastal bottlenose dolphins (Tursiops truncatus). Marine Mammal Science 28, E1-E15.

*Coulson, J. O., Coulson, T. D., DeFrancesch, S. A. \& Sherry, T. W. (2008). Predators of the swallow-tailed kite in southern Louisiana and Mississippi. fournal of Raptor Research 42, 1-12.

Courchamp, F., Langlais, M. \& Sugihara, G. (1999). Cats protecting birds: modelling the mesopredator release effect. Fournal of Animal Ecology 68, 282-292.

*Cove, M. V., Jones, B. M., Bossert, A. J., Cleverer, D. R., Dunwoody, R K., White, B. C. \& Jackson, V. L. (2012). Use of camera traps to examine the mesopredator release hypothesis in a fragmented midwestern landscape. American Midland Naturalist 168, 456-465.

*Cozzi, G., Broekhuis, F., McNutt, J. W., Turnbull, L. A., Macdonald, D. W. \& Schmid, B. (2012). Fear of the dark or dinner by moonlight? Reduced temporal partitioning among Africa's large carnivores. Ecology 93, 2590-2599.

* Creel, S. (2001). Four factors modifying the effect of competition on carnivore population dynamics illustrated by African wild dogs. Conservation Biology 15 $271-274$.

*Creel, S. \& Creel, N. M. (1996). Limitation of African wild dogs by competition with larger carnivores. Conservation Biology 10, 526-538.

*Creel, S. \& Creel, N. M. (1998). Six ecological factors that may limit African wild dogs, Lycaon pictus. Animal Conservation 1, 1-9.

*Crooks, K. C. \& Soulé, M. E. (1999). Mesopredator release and avifaunal extinctions in a fragmented system. Nature 400, 563-566.

*Cupples, J. B., Crowther, M. S., Story, G. \& Letnic, M. (2011). Dietary overlap and prey selectivity among sympatric carnivores: could dingoes suppress foxes through competition for prey? Fournal of Mammalogy 92, 590-600. 
*Davis, M. L., Kelly, M. J. \& Stauffer, D. F. (2011). Carnivore co-existence and habitat use in the Mountain Pine Ridge Forest Reserve, Belize. Animal Conservation 14, 56-65.

De Feo, O. \& Rinaldi, S. (1997). Yield and dynamics of tritrophic food chains. American Naturalist 150, 328-345.

*Di Bitetti, M. S., De Angelo, C. D., Di Blanco, Y. E. \& Paviolo, A. (2010). Niche partitioning and species coexistence in a Neotropical felid assemblage. Acta Oecologica 36, 403-412.

*Donadio, E. \& Buskirk, S. W. (2006). Diet, morphology, and interspecific killing in Carnivora. American Naturalist 167, 524-536.

*Doncaster, C. P. (1992). Testing the role of intraguild predation in regulating hedgehog populations. Proceedings of the Royal Society B 249, 113-117.

Driscoll, D. A. \& Lindenmayer, D. B. (2012). Framework to improve the application of theory in ecology and conservation. Ecological Monographs 82, 129-147.

*Dumont, Y., Russel, J. C., Lecomte, V. \& Le Corre, M. (2010). Conservation of endangered endemic seabirds within a multi-predator context: the Barau's petrel in Réunion Island. Natural Resource Modeling 23, 381-436.

*Durant, S. M. (1998). Competition refuges and coexistence: an example from Serengeti carnivores. Fournal of Animal Ecology 67, 370-386.

*Durant, S. M. (2000). Living with the enemy: avoidance of hyenas and lions by cheetahs in the Serengeti. Behavioral Ecology 11, 624-632.

*Ellis, D. H., Tsengeg, P., Whitlock, P. \& Ellis, M. H. (1999). Predators as prey at a Golden Eagle Aquila chrysaetos eyrie in Mongolia. Ibis 141, 139-158.

*Elmhagen, B., Ludwig, G., Rushton, S. P., Helle, P. \& Lindén, H. (2010). Top predators, mesopredators and their prey: interference ecosystems along bioclimatic productivity gradients. Fournal of Animal Ecology 79, 785-794.

*Eloff, F. C. (1984). Food ecology of the Kalahari lion Panthera leo vernayi. Koedoe 27, $249-258$.

Essington, T. E., Beaudreau, A. H. \& Wiedenmann, J. (2006). Fishing through marine food webs. Proceedings of the National Academy of Sciences 103, 3171-3175.

Estes, J., Crooks, K. \& Holt, R. (2001). Predators, ecological role of. In Encyclopedia of Biodiversity (Volume 4, ed. S. A. Levin), pp. 857-878. Academic Press, Waltham.

*Estes, J. A., Tinker, M. T., Williams, T. M. \& Doak, D. F. (1998). Killer whale predation on sea otters linking oceanic and nearshore ecosystems. Science 282, $473-476$.

*Farías, V., Fuller, T. K. \& Sauvajot, R. M. (2012). Activity and distribution of gray foxes (Urocyon cinereoargenteus) in Southern California. Southwestern Naturalist 57, $176-181$.

*Farías, V., Fuller, T. K., Wayne, R. K. \& Sauvajot, R. M. (2005). Survival and cause-specific mortality of gray foxes (Urocyon cinereoargenteus) in southern California. Fournal of Zoology 266, 249-254.

FAUTH, J. E. (1990). Interactive effects of predators and early larval dynamics of the treefrog Hyla chrysocelis. Ecology 71, 1609-1616.

Fauth, J. E., Bernardo, J., Camara, M., Resetarits, W. J., Van Buskirk, J. \& McCollum, S. A. (1996). Simplifying the jargon of community ecology: a conceptual approach. American Naturalist 147, 282-286.

*Fedriani, J. M., Fuller, T. K., Sauvajot, R. M. \& York, E. C. (2000). Competition and intraguild predation among three sympatric carnivores. Oecologia 125, 258-270.

*Fedriani, J. M., Palomares, F. \& Delibes, M. (1999). Niche relations among three sympatric Mediterranean carnivores. Oecologia 121, 138-148.

*Ferretti, F., Worm, B., Britten, G. L., Heithaus, M. R. \& Lotze, H. K. (2010). Patterns and ecosystem consequences of shark declines in the ocean. Ecology Letters 13, 1055-1071.

*Fertl, D., Acevedo-Gutiérrez, A. \& Darby, F. L. (1996). A report of killer whales (Orcinus orca) feeding on a carcharhinid shark in Costa Rica. Marine Mammal Science 12, 606-611.

*Frafjord, K., Becker, D. \& Angerbjörn, A. (1989). Interactions between arctic and red foxes in Scandinavia - predation and aggression. Arctic 42, 354-356.

Fretwell, S. D. (1987). Food chain dynamics: the central theory of ecology? Oikos 50, 291-301.

*Gainzarain, J. A., Arambarri, R. \& Rodríguez, A. F. (2000). Breeding density, habitat selection and reproductive rates of the peregrine falcon Falco peregrinus in Álava (northern Spain). Bird Study 47, 225-231.

*Gainzarain, J. A., Arambarri, R. \& Rodríguez, A. F. (2002). Population size and factors affecting the density of the peregrine falcon Falco peregrinus in Spain. Ardeola 49, $67-74$.

*Gehrt, S. D. \& Clark, W. R. (2003). Racoons, coyotes, and reflections on the mesopredator release hypothesis. Wildlife Society Bulletin 31, 836-842.

*Gehrt, S. D. \& Prange, S. (2007). Interference competition between coyotes and raccoons: a test of the mesopredator release hypothesis. Behavioral Ecology 18, 204-214.

*GeORgE, J. R. (1989). Bald eagle kills sharp-shinned hawk. Fournal of Raptor Research $23,55-56$.

*Ginsberg, J. R., Alexander, K. A., Creel, S., Kat, P. W., McNutt, J. W. \& Mills, M. G. L. (1995). Handling and survivorship of African wild dog (Lycaon pictus) in five ecosystems. Conservation Biology 9, 665-674.
*Glen, A. S. \& Dickman, C. R. (2005). Complex interactions among mammalian carnivores in Australia, and their implications for wildlife management. Biological Reviews 80, 387-401.

*Glen, A. S. \& Dickman, C. R. (2008). Niche overlap between marsupial and eutherian carnivores: does competition threaten the endangered spotted-tailed quoll. Fournal of Applied Ecology 45, 700-707.

*Glen, A. S., Pennay, M., Dickman, C. R., Wintle, B. A. \& Firestone, K. B. (2011). Diets of sympatric native and introduced carnivores in the Barrington Tops, eastern Australia. Austral Ecology 36, 290-296.

*Hakkarainen, H. \& KorpimäKi, E. (1996). Competitive and predatory interactions among raptors: an observational and experimental study. Ecology 77, 1134-1142.

*Hakkarainen, H., Mykrä, S., Kurki, S., Tornberg, R. \& Jungell, S. (2004). Competitive interactions among raptors in boreal forests. Oecologia 141, 420-424.

*Harmsen, B. J., Foster, R. J., Silver, S. C., Ostro, L. E. T. \& Doncaster, C. P. (2009). Spatial and temporal interactions of sympatric jaguars (Panthera onca) and pumas (Puma concolor) in a neotropical forest. Fournal of Mammalogy 90, 612-620.

*Harrington, L. A., Harrington, A. L., Yamagughi, N., Thom, M. D., Ferreras, P., Windham, T. R. \& MacDonald, D. W. (2009). The impact of native competitors on an alien invasive: temporal niche shifts to avoid interspecific aggression? Ecology 90, 1207-1216.

*Hass, C. C. (2009). Competition and coexistence in sympatric bobcats and pumas. fournal of Zoology 278, 174-180.

Hawkins, C. P. \& MacMahon, J. A. (1989). Guilds: the multiple meanings of a concept. Annual Review of Entomology 34, 423-451.

*Hayes, R. D. \& BaER, A. (1992). Brown bear, Ursus arctos, preying upon gray wolf, Canis lupus, pups at a wolf den. Canadian Field-Naturalist 106, 381-382.

*Hayward, M. W. \& Kerley, G. I. H. (2008). Prey preferences and dietary overlap amongst Africa's large predators. South African Foumal of Wildlife Research 38, 93-108.

*Hayward, M. W. \& Slotow, R. (2009). Temporal partitioning of activity in large African carnivores: tests of multiple hypotheses. South African fournal of Wildlife Research $39,109-125$.

Hayward, M. W. \& Somers, M. J. (2009). Reintroduction of top-order predators. WileyBlackwell, Oxford.

*Heithaus, M. R. (2001). Predator-prey and competitive interactions between sharks (order Selachii) and dolphins (suborder Odontoceti): a review. Fournal of Zoology 253, 53-68.

*Heithaus, M. R. \& Dill, L. M. (2002). Food availability and tiger shark predation risk influence bottlenose dolphin habitat use. Ecology 83, 480-491.

*Heithaus, M. R. \& Dill, L. M. (2006). Does tiger shark predation risk influence foraging habitat use by bottlenose dolphins at multiple spatial scales? Oikos 114, $257-264$.

Heithaus, M. R., Frid, A., Wirsing, A.J. \& Worm, B. (2008). Predicting ecological consequences of marine top predator declines. Trends in Ecology and Evolution 23, $202-210$.

*Helldin, J. O., Liberg, O. \& Glöersen, G. (2006). Lynx (Lynx lynx) killing red foxes (Vulpes vulpes) in boreal Sweden - frequency and population effects. Fournal of Zoology 270, 657-663.

*Henden, J. A., Ims, R. A., Yoccoz, N. G., Hellström, P. \& Agerbjörn, A. (2010). Strength of asymmetric competition between predators in food webs ruled by fluctuating prey: the case of foxes in tundra. Oikos 119, 27-34.

Herrera, C. M. \& Hiraldo, F. (1976). Food-niche and trophic relationships among European owls. Ornis Scandinavica 7, 29-41.

*Hersteinsson, P. \& MacDonald, D. W. (1992). Interspecific competition and the geographical distribution of red and arctic foxes Vulpes vulpes and Alopex lagopus. Oikos $64,505-515$.

*Horejsi, B. L., Hornbeck, G. E. \& Raine, R. M. (1984). Wolves, Canis lupus, kill female black bear, Ursus americanus, in Alberta. Canadian Field-Naturalist 98, 368-369.

*Hoset, K. S., Koivisto, E., Huitu, O., Ylönen, H. \& Korpimäki, E. (2009). Multiple predators induce risk reduction in coexisting vole species. Oikos 118, $1421-1429$.

*Hudgens, B. R. \& Garcelon, D. K. (2011). Induced changes in island fox (Urocyon littoralis) activity do not mitigate the extinction threat posed by a novel predator. Oecologia 165, 699-705.

*Hunter, J. \& Caro, T. (2008). Interspecific competition and predation in American carnivore families. Ethology Ecology and Evolution 20, 295-324.

*Hunter, J. S., Durant, S. M. \& Caro, T. M. (2007). To flee or not to flee: predator avoidance by cheetahs at kills. Behavioral Ecology and Sociobiology 61, 1033-1042.

Jaksić, F. M. (1981). Abuse and misuse of the term "guild" in ecological studies. Oikos 37, $397-400$.

Jaksıć, F. M. (1988). Trophic structure of some Nearctic, Neotropical and Palearctic owl assemblages: potential roles of diet opportunism, interspecific interference and resource depression. Fournal of Raptor Research 22, 44-52.

*Jefferson, T. A., Stacey, P. J. \& Baird, R. W. (1991). A review of killer whale interactions with other marine mammals: predation to co-existence. Mammal Review 21, $151-180$.

*Jimenez, M. D., Asher, V. J., Bergman, C., Bangs, E. E. \& Woodruff, S. P. (2008). Gray wolves, Canis lupus, killed by cougars, Puma concolor, and a grizzly 
bear, Ursus arctos, in Montana, Alberta, and Wyoming. Canadian Field-Naturalist 122, $76-78$.

*Johnson, C. N., IsAaC, J. L. \& Fisher, D. O. (2007). Rarity of a top predator triggers continent-wide collapse of mammal prey: dingoes and marsupials in Australia. Proceedings of the Royal Society B 274, 341-346.

*Johnson, C. N. \& VANDerWAL, J. (2009). Evidence that dingoes limit abundance of a mesopredator in eastern Australian forests. Fournal of Applied Ecology 46, 641-646.

*Kamler, J. F., Stenkewitz, U., Klare, U., Jacobsen, N. F. \& MacDonald, D. W. (2012). Resource partitioning among cape foxes, bat-eared foxes, and black-backed jackals in South Africa. Fournal of Wildlife Management 76, 1241-1253.

*Kelly, E. G., Forsman, E. D. \& Anthony, R. G. (2003). Are barred owls displacing spotted owls? Condor 105, 45-53.

*Klem, D., Hillegrass, B. S. \& Peters, D. A. (1985). Raptors killing raptors. Wilson Bulletin 97, 230-231.

KoRPIMÄKI, E. (1987). Dietary shifts, niche relationships and reproductive output of coexisting Kestrels and Long eared Owls. Oecologia 74, 277-285.

*KorpimäKI, E. \& NorRdahl, K. (1989a). Avian predation on mustelids in Europe 1: occurrence and effects on body size variation and life traits. Oikos 55, 205-215.

*KorpimäKi, E. \& Norrdahl, K. (1989b). Avian predation on mustelids in Europe 2: impact on small mustelid and microtine dynamics - a hypothesis. Oikos 55, $273-276$

*Kostrzewa, A. (1991). Interspecific interference competition in three European raptor species. Ethology Ecology and Evolution 3, 127-143.

KRÜGER, O. (2002). Interactions between common buzzard Buteo buteo and goshawk Accipiter gentilis: trade-offs revealed by a field experiment. Oikos $\mathbf{9 6}, 441-452$.

*Kruuk, H. \& Turner, M. (1967). Comparative notes on predation by lion, leopard, cheetah and wild dog in the Serengeti area, east Africa. Mammalia 31, 1-27.

*Kurki, S., Nikula, A., Helle, P. \& Lindén, H. (1998). Abundances of red fox and pine marten in relation to the composition of boreal forest landscapes. Fournal of Animal Ecology 67, 874-886.

*Leskiw, T. \& Gutiérrez, R. J. (1998). Possible predation of a spotted owl by a barred owl. Western Birds 29, 225-226.

*Letnic, M., Crowther, M. S. \& Koch, F. (2009). Does a top-predator provide an endangered rodent with refuge from an invasive mesopredator? Animal Conservation 12, 302-312.

*Letnic, M. \& Dworjanyn, S. A. (2011). Does a top predator reduce the predatory impact of an invasive mesopredator on an endangered rodent? Ecography 34, $827-835$.

*Letnic, M., Fillios, M. \& Crowther, M. S. (2012). Could direct killing by larger dingoes have caused the extinction of the thylacine from mainland Australia? PLoS ONE 7, e34877.

*Letnic, M., Greenville, A., Denny, E., Dickman, G. R., Tischler, M., Gordon, C. \& Koch, F. (2011). Does a top predator suppress the abundance of an invasive mesopredator at a continental scale? Global Ecology and Biogeography 20, $343-353$.

*Levi, T. \& Wilmers, C. C. (2012). Wolves-coyotes-foxes: a cascade among carnivores. Ecology 93, 921-929.

*Levin, S. A., Levin, J. E. \& Paine, R. T. (1977). Snowy owl predation on short-eared owls. Condor 79, 395.

*Lindström, E. R., Brainerd, S. C., Helldin, J. O. \& Overskaug, K. (1995). Pine marten - red fox interactions: a case of intraguild predation? Annales Zoologici Fennici 32, 123-130

*Linnell, J. D. C., Odden, J., Pedersen, V. \& Andersen, R. (1998). Records of intra-guild predation by Eurasian Lynx, Lynx lynx. Canadian Field-Naturalist 112, $707-708$

*Linneld, J. D. C. \& Strand, O. (2000). Interference interactions, co-existence and conservation of mammalian carnivores. Diversity and Distributions 6, 169-176.

*Lourenço, R., Penteriani, V., Delgado, M. M., Marchi-Bartolozzi, M. \& RABAÇA, J. E. (2011a). Kill before being killed: an experimental approach supports the predator removal hypothesis as a determinant of intraguild predation in top predators. Behavioral Ecology and Sociobiology 65, 1709-1714.

*Lourenço, R., Santos, S. M., Rabaça, J. E. \& Penteriani, V. (2011b). Superpredation patterns in four large European raptors. Population Ecology 53, $175-185$

*Lourenço, R., Tavares, P. C., Delgado, M. M., RabaÇa, J. E. \& Penteriani, V. $(2011 c)$. Superpredation increases mercury levels in a generalist top predator, the eagle owl. Ecotoxicology 20,635-642.

*Luttich, S. N., Keith, L. B. \& Stephenson, J. D. (1971). Population dynamics of the red-tailed hawk (Buteo jamaicensis) at Rochester, Alberta. Auk 88, 75-87.

*MacDonald, J. (1994). Bald Eagle attacks adult Osprey. Foumal of Raptor Research 28, 122

*MacLeod, R., Macleod, C. D., Learmonth, J. A., Jepson, P. D., Reid, R. J., Deaville, R. \& Pierce, G. J. (2007). Mass-dependent predation risk and lethal dolphin-porpoise interactions. Proceedings of the Royal Society B 274, 2587-2593.

Mac Nally, R. C. (1983). On assessing the significance of interspecific competition to guild structure. Ecology 64, 1646-1652.
Mac Nally, R., Fleishman, E., Thomson, J. R. \& Dobkin, D. S. (2008). Use of guilds for modelling avian responses to vegetation in the Intermountain West (USA). Global Ecology and Biogeography 17, 758-769.

*Malo, A. F., Lozano, J., Huertas, D. L. \& Virgós, E. (2004). A change of diet from rodents to rabbits (Oryctolagus cuniculus). Is the wildcat (Felis silvestris) a specialist predator? Fournal of Zoology 263, 401-407.

*Maran, T. \& Henttonen, H. (1995). Why is the European mink (Mustela lutreola) disappearing? - a review of the process and hypotheses. Annales Zoologici Fennici 32, $47-54$.

Marti, G. M., Korpimäki, E. \& Jaksić, F. M. (1993). Trophic structure of raptor communities: a three-continent comparison and synthesis. Current Ormithology 10 $47-137$.

*Martínez, J. E., Martínez, J. A., Zuberogoitia, I., Zabala, J., Redpath, S. M. \& Calvo, J. F. (2008). The effect of intra- and interspecific interactions on the large-scale distribution of cliff-nesting raptors. Ornis Fennica 85, 13-21.

*Mateo, P. \& Olea, P. P. (2007). Egyptian vultures (Neophron percnopterus) attack golden eagles (Aquila chrysaetos) to defend their fledgling. Fournal of Raptor Research 41, 339-340.

*Mátics, R., Bank, L., Varga, S., Klein, A. \& Hoffmann, G. (2008). Interspecific offspring killing in owls. Biological Journal of the Linnean Society 95, 488-494.

*Mattisson, J., Andrén, H., Persson, J. \& Segerström, P. (2011). Influence of intraguild interactions on resource use by wolverines and Eurasian lynx. Foumal of Mammalogy 92, 1321-1330.

*McDonald, R. A. (2002). Resource partitioning among British and Irish mustelids. Fournal of Animal Ecology 71, 185-200.

*McDonald, R. A., O’Hara, K. \& Morrish, D. J. (2007). Decline of invasive alien mink (Mustela vison) is concurrent with recovery of native otters (Lutra lutra). Diversity and Distributions 13, 92-98.

*McInvaille, W. B. \& Keith, L. B. (1974). Predator-prey relations and breeding biology of the Great horned owl and Red-tailed hawk in Central Alberta. Canadian Field-Naturalist 88, 1-20.

*MıккоLa, H. (1976). Owls killing and killed by other owls and raptors in Europe. British Birds 69, 144-154.

*Miller, K. E. (2005). Red-tailed hawk depredates Mississippi kite nestling at dawn Journal of Raptor Research 39, 108.

*Mitchell, B. D. \& Banks, P. B. (2005). Do wild dogs exclude foxes? Evidence for competition from dietary and spatial overlaps. Austral Ecology 30, 581-591.

*Moehrenschlager, A., List, R. \& MacDonald, D. W. (2007). Escaping intraguild predation: Mexican kit foxes survive while coyotes and golden eagles kill Canadian swift foxes. Fournal of Mammalogy 88, 1029-1039.

*Moleón, M. \& Gil-SÁnchez, J. M. (2003). Food habits of the wildcat (Felis silvestris) in a peculiar habitat: the Mediterranean high mountain. Fournal of Zoology 260, $17-22$.

*Moreno, R. S., Kays, R. W. \& Samudio, R. (2006). Competitive release in diets of ocelot (Leopardus pardalis) and puma (Puma concolor) after jaguar (Panthera onca) decline. fournal of Mammalogy 87, 808-816.

Muñoz, A. A. \& OJEDA, F. P. (1998). Guild structure of carnivorous intertidal fishes of the Chilean coast: implications of ontogenetic dietary shifts. Oecologia 114, 563-573.

*Myers, R. A., Baum, J. K., Shepherd, T. D., Powers, S. P. \& Peterson, C. H. (2007). Cascading effects of the loss of apex predatory sharks from a coastal ocean. Science 315, 1846-1850.

*Neale, J. C. C. \& Sacks, B. N. (2001). Food habits and space use of gray foxes in relation to sympatric coyotes and bobcats. Canadian fournal of Zoology 79, 1794-1800.

*Ngoprasert, D., Lynam, A. J., Sukmasuang, R., Tantipisanuh, N., Chutipong, W., Steinmetz, R., Jenks, K. E., Gale, G. A., Grassman, L. I., Kitamura, S., Howard, J., Cutter, P., Cutter, P., Leimgruber, P., Songsasen, N. \& ReED, D. H. (2012). Occurrence of three felids across a network of protected areas in Thailand: prey, intraguild, and habitat associations. Biotropica 44, 810-817.

*Odden, M., Wegge, P. \& Fredriksen, T. (2010). Do tigers displace leopards? If so, why? Ecological Research 25, 875-881.

*Olson, G. S., Anthony, R. G., Forsman, E. D., Ackers, S. H., Loschl, P. J. Reid, J. A., Dugger, K. M., Glenn, E. M. \& Ripple, W. J. (2005). Modeling of site occupancy dynamics for northern spotted owls, with emphasis on the effects of barred owls. Fournal of Wildlife Management 69, 918-932.

*Palomares, F. \& Caro, T. M. (1999). Interspecific killing among mammalian carnivores. American Naturalist 153, 492-508.

*Palomares, F., Ferreras, P., Fedriani, J. M. \& Delibes, M. (1996). Spatial relationships between Iberian lynx and other carnivores in an area of south-western Spain. Journal of Applied Ecology 33, 5-13.

*Palomares, F., Ferreras, P., Traivani, A. \& Delibes, M. (1998). Co-existence between Iberian lynx and Egyptian mongooses: estimating interaction strength by structural equation modelling and testing by an observational study. Fournal of Animal Ecology 67, 967-978.

*Palomares, F., Gaona, P., Ferreras, P. \& Delibes, M. (1995). Positive effects on game species of top predators by controlling smaller predator populations: an example with lynx, mongooses, and rabbits. Conservation Biology 9, 295-305. 
*Pamperin, N. J., Follmann, E. H. \& Petersen, B. (2006). Interspecific killing of an Arctic fox by a red fox at Prudhoe Bay, Alaska. Arctic 59, 361-364.

*PaQuet, P. C. \& Carbyn, L. N. (1986). Wolves, Canis lupus, killing denning black bears, Ursus americanus, in the Riding Mountain National Park area. Canadian Field-Naturalist 100, 371-372.

*Patterson, I. A. P., Reid, R. J., Wilson, B., Grellier, K., Ross, H. M. \& Thompson, P. M. (1998). Evidence for infanticide in bottlenose dolphins: an explanation for violent interactions with harbour porpoises? Proceedings of the Royal Society $B$ 265, 1167-1170.

*Pearson, R. R. \& Livezey, K. B. (2003). Distribution, numbers, and site characteristics of spotted owls and barred owls in the Cascade Mountains of Washington. Fournal of Raptor Research 37, 265-276.

*Perkins, D. W., Phillips, D. M. \& Garcelon, D. K. (1996). Predation on a bald eagle nestling by a red-tailed hawk. fournal of Raptor Research 30, 249.

Persson, L. (1985). Asymmetrical competition: are larger animals competitively superior? American Naturalist 126, 261-266.

*Petty, S. J., Anderson, D. I. K., Davison, M., Little, B., Sherratt, T. N., Thomas, G. J. \& Lambin, X. (2003). The decline of common kestrels Falco timnunculus in a forested area of northern England: the role of predation by northern goshawks Accipiter gentilis. Ibis 145, 472-483.

PIANKa, E. R. (1980). Guild structure in desert lizards. Oikos 35, 194-201.

Pimm, S. L. (2002). Food Webs. Second Edition. University of Chicago Press, Chigaco.

Pimm, S. L. \& Lawton, J. H. (1978). On feeding on more than one trophic level. Nature 275, 542-544.

Polis, G. A. \& Holt, R. D. (1992). Intraguild predation: the dynamics of complex trophic interactions. Trends in Ecology and Evolution 7, 151-154.

Polis, G. A. \& MCCormick, S. J. (1986). Scorpions, spiders and solpugids: predation and competition among distantly related taxa. Oecologia $71,111-116$.

Polis, G. A. \& McCormick, S. J. (1987). Intraguild predation and competition among desert scorpions. Ecology 68, 332-343.

Polis, G. A., Myers, C. A. \& Holt, R. D. (1989). The ecology and evolution of intraguild predation: potential competitors that eat each other. Annual Review of Ecology and Systematics 20, 297-330.

Post, D. M. (2002). The long and short of food-chain length. Trends in Ecology and Evolution 17, 269-277.

*Prange, S. \& Gehrt, S. D. (2007). Response of skunks to a simulated increase in coyote activity. Fournal of Mammalogy 88, 1040-1049.

Prugh, L., Stoner, G. J., Epps, C. W., Bean, W. T., Ripple, W. J., Laliberte, A. S. \& Brashares, J. S. (2009). The rise of the mesopredator. BioScience 59, 779-791.

*Pyle, P., Schramm, M. J., Keiper, C. \& Anderson, S. D. (1999). Predation on a white shark (Carcharodon carcharias) by a killer whale (Orcinus orca) and a possible case of competitive displacement. Marine Mammal Science 15, 563-568.

*Ralls, K. \& White, P. J. (1995). Predation on San Joaquin kit foxes by larger canids. Fournal of Mammalogy 76, 723-729.

*Real, J. \& Mañosa, S. (1990). Eagle owl (Bubo bubo) predation on juvenile Bonelli's eagles (Hieraaetus fasciatus). Fournal of Raptor Research 24, 69-71.

*Remonti, L., Balestrieri, A., Ruiz-González, A., Gómez-Moliner, B. J., Capelli, E. \& Prigioni, C. (2012). Intraguild dietary overlap and its possible relationship to the coexistence of mesocarnivores in intensive agricultural habitats. Population Ecology 54, 521-532.

*Reyes, L. M. \& García-Borboroglu, P. (2004). Killer whale (Orcinus orca) predation on sharks in Patagonia, Argentina: a first report. Aquatic Mammals 30, 376-379.

Rinaldi, S. \& MURATORI, S. (1992). Slow-fast limit cycles in predator-prey models. Ecological Modelling 61, 287-308.

*Ritchie, E. G. \& Johnson, G. N. (2009). Predator interactions, mesopredator release and biodiversity conservation. Ecology Letters 12, 982-998.

*Roemer, G. W., Donlan, C. J. \& Courchamp, F. (2002). Golden eagles, feral pigs, and insular carnivores: how exotic species turn native predators into prey. Proceedings of the National Academy of Sciences 99, 791-796.

*Roemer, G. W., Gompper, M. E. \& Van Valkenburgh, B. (2009). The ecological role of the mammalian mesocarnivore. Bioscience 59, 165-173.

*Rogers, C. M. \& Caro, M. J. (1998). Song sparrows, top carnivores and nest predation: a test of the mesopredator release hypothesis. Oecologia 116, 227-233.

*Rohner, C. \& Doyle, F. I. (1992). Food-stressed great horned owl kills adult goshawk: exceptional observation or community process? Fournal of Raptor Research 26, 261-263.

RoOT, R. B. (1967). The niche exploitation pattern of the blue-grey gnatcatcher. Ecological Monographs 37, 317-350.

*Ross, H. M. \& WiLson, B. (1996). Violent interactions between bottlenose dolphins and harbour porpoises. Proceedings of the Royal Society B 263, 283-286.

*Roth, T. C. \& Lima, S. L. (2007). The predatory behavior of wintering Accipiter hawks: temporal patterns in activity of predators and prey. Oecologia 152, 169-178.

*Roth, T. C., Lima, S. L. \& VetTer, W. E. (2005). Survival and causes of mortality in wintering sharp-shinned hawks and Cooper's hawks. Wilson Bulletin 117, 237-244.

*Route, W. T. \& Peterson, R. O. (1991). An incident of wolf, Canis lupus, predation on a river otter, Lutra canadensis, in Minnesota. Canadian Field-Naturalist 105, 567-568. *Rudolph, S. G. (1978). Predation ecology of coexisting Great Horned and Barn owls. Wilson Bulletin 90, 134-137.
Ruiz-Olmo, J. \& Marsol, R. (2002). New information on the predation of fish eating birds by the Eurasian Otter (Lutra lutra). IUCN Otter Specialist Group Bulletin 19, 103-106.

Russel, J. C., Lecomte, V., Dumont, Y. \& Le Corre, M. (2009). Intraguild predation and mesopredator release effect on long-lived prey. Ecological Modelling 220, $1098-1104$.

*Rutz, C. \& Bijlsma, R. G. (2006). Food-limitation in a generalist predator. Proceedings of the Royal Society B 273, 2069-2076.

*ŠÁlek, M., Kreisinger, J., Sedláček, F. \& Albrecht, T. (2010). Do prey densities determine preferences of mammalian predators for habitat edges in an agricultural landscape? Landscape and Urban Planning 98, 86-91.

*Saleni, P., Gusset, M., Graf, J. A., Szykman, M., Walters, M. \& Somers, M. J. (2007) Refuges in time: temporal avoidance of interfere competition in endangered wild dogs Lycaon pyctus. Canid Neres 10.2 [online]. Available at www.canids.org/ canidnews/10/interference_competition_in_wild_dogs.pdf. Accessed 27.7.2012.

*Salo, P., Nordström, M., Thomson, R. L. \& KorpimäKi, E. (2008). Risk induced by a native top predator reduces alien mink movements. Fournal of Animal Ecology 77, $1092-1098$.

SCHEINER, S. M. (2010). Toward a conceptual framework for biology. Quarterly Review of Biology 85, 293-318.

*Schmidt, N. M., Ims, R. A., Høye, T. T., Gilg, O., Hansen, L. H., Hansen, J., Lund, M., Fuglei, E., Forchhammer, M. C. \& Sittler, B. (2012). Response of an arctic predator guild to collapsing lemming cycles. Proceedings of the Royal Society $B$ $279,4417-4422$.

Schmitz, O. J., Намвӓск, P. A. \& Beckerman, A. P. (2000). Trophic cascades in terrestrial systems: a review of the effects of carnivore removals on plants. American Naturalist 155, 141-153.

Schoener, T. W. (1983). Field experiments on interspecific competition. American Naturalist 122, 240-285.

Sergio, F., Caro, T., Brown, D., Clucas, B., Hunter, J., Ketchum, J., McHugh, K. \& HiraLdo, F. (2008). Top predators as conservation tools: ecological rationale, assumptions, and efficacy. Annual Review of Ecology Evolution and Systematics 39, 1-19.

*Sergio, F. \& Hiraldo, F. (2008). Intraguild predation in raptor assemblages: a review. Ibis 150(suppl. 1), 132-145.

*Sergio, F., Marchesi, L. \& Pedrini, P. (2003). Spatial refugia and the coexistence of a diurnal raptor with its intraguild owl predator. Fournal of Animal Ecology 72, 232-245.

*Sergio, F., Marchesi, L., Pedrini, P. \& Penteriani, V. (2007). Coexistence of a generalist owl with its intraguild predator: distance-sensitive or habitat-mediated avoidance? Animal Behaviour 74, 1607-1616.

*Serrano, D. (2000). Relationship between raptors and rabbits in the diet of eagle owls in southwestern Europe: competition removal or food stress? Foumal of Raptor Research 34, 305-310.

SimberLoff, D. \& DAyAn, T. (1991). The guild concept and the structure of ecological communities. Annual Review of Ecology and Systematics 22, 115-143.

*Smith, M. E. \& Follmann, E. H. (1993). Grizzly bear, Ursus arctos, predation of a denned adult black bear, U. americanus. Canadian Field-Naturalist 107, 97-99.

Smouse, P. E. (1981). Mathematical models for continuous culture growth dynamics of mixed populations subsisting on a heterogeneous resource base II. Predation and trophic structure. Theoretical Population Biology 20, 127-149.

*Solonen, T. (1993). Spacing of birds of prey in southern Finland. Ormis Fennica 70, 129-143.

*Solonen, T. (2011). Impact of dominant predators on territory occupancy and reproduction of subdominant ones within a guild of birds of prey. Open Omithology fournal 4, 23-29.

*Sørensen, O. J., Totsås, M., Solstad, T. \& Rigg, R. (2008). Predation by a golden eagle on a brown bear cub. Ursus 19, 190-193.

*Soulé, M. C., Bolger, D. T., Alberts, A. C., Wright, J., Sorice, M. \& Hill, S. (1988). Reconstructed dynamics of rapid extinctions of chaparral-requiring birds in urban habitat islands. Conservation Biology 2, 75-92.

Southern, H. N. (1947). Review: predator-prey relations. Fournal of Animal Ecology 16, $226-227$.

*Spitz, J., Rousseau, Y. \& Ridoux, V. (2006). Diet overlap between harbour porpoise and bottlenose dolphin: an argument in favour of interference competition for food? Estuarine, Coastal and Shelf Science 70, 259-270.

*STANDER, P. E. (1992). Foraging dynamics of lions in a semi-arid environment. Canadian foumal of Zoology 70, 8-21.

*Stephenson, R. O., Grangaard, D. V. \& Burch, J. (1991). Lynx, Felis lynx, predation on red foxes, Vulpes vulpes, caribou, Rangifer tarandus, and Dall sheep, Ovis dalli, in Alaska. Canadian Field-Naturalist 105, 255-262.

*St-Pierre, C., Ouellet, J.-P. \& Crête, M. (2006). Do competitive intraguild interactions affect space and habitat use by small carnivores in a forested landscape. Ecography 29, 487-496.

*Sunde, P., Overskaug, K. \& Kvam, T. (1999). Intraguild predation of lynxes on foxes: evidence of interference competition? Ecography 22, 521-523.

*Sutherland, D. R., Glen, A. S. \& de Tores, P. J. (2011). Could controlling mammalian carnivores lead to mesopredator release of carnivorous reptiles? Proceedings of the Royal Society B 278, 641-648. 
*Tannerfeldt, M., Elmhagen, B. \& Angerbjörn, A. (2002). Exclusion by interference competition? The relationship between red and arctic foxes. Oecologia $132,213-220$.

*Tella, J. L., Carrete, M., Sánchez-Zapata, J. A., Serrano, D., Gavrilov, A., Sklyarenko, S., Ceballos, O., Donázar, J. A. \& Hiraldo, F. (2004). Effects of land use, nesting-site availability, and the presence of larger raptors on the abundance of vulnerable lesser kestrels Falco naumanni in Kazakhstan. Oryx 38, $224-227$.

*Tella, J. L. \& Mañosa, S. (1993). Eagle owl predation on Egyptian vulture and northern goshawk: possible effect of a decrease in European rabbit availability. Journal of Raptor Research 27, 111-112.

*Thompson, C. M. \& Gese, E. M. (2007). Food webs and intraguild predation: community interactions of a native mesocarnivore. Ecology 88, 334-346.

*Treinys, R., Dementavičius, D., Mozgeris, G., Skuja, S., Rumbutis, S. \& STončius, D. (2011). Coexistence of protected avian predators: does a recovering population of white-tailed eagle threaten to exclude other avian predators? European Fournal of Wildlife Research 57, 1165-1174.

*Trewby, I. D., Wilson, G. J., Delahay, R. J., Walker, N., Young, R., Davison, J., Cheeseman, C., Robertson, P. A., Gorman, M. L. \& McDonald, R. A. (2008). Experimental evidence of competitive release in sympatric carnivores. Biology Letters 4, 170-172.

*Van Lanen, N. L., Franklin, A. B., Huyvaert, K. P., Reiser, R. F. \& Carlson, P. G. (2011). Who hits and hoots at whom? Potential for interference competition between barred and northern spotted owls. Biological Conservation 144, 2194-2201.

*Vanak, A. T. \& Gomprer, M. E. (2010). Interference competition at the landscape level: the effect of free-ranging dogs on a native mesocarnivore. Fournal of Applied Ecology 47, 1225-1232.

*Vanak, A. T., Thaker, M. \& Gomprer, M. E. (2009). Experimental examination of behavioural interactions between free-ranging wild and domestic canids. Behavioral Ecology and Sociobiology 64, 279-287.

*Viota, M., Rodríguez, A., López-Bao, J. V. \& Palomares, F. (2012). Shift in microhabitat use as a mechanism allowing the coexistence of victim and killer carnivore predators. Open Fournal of Ecology 2, 115-120.

*Visser, I. N. (2005). First observations of feeding on thresher (Alopias vulpinus) and hammerhead (Sphyma zygaena) sharks by killer whales (Orcinus orca), which specialise on elasmobranchs as prey. Aquatic Mammals 31, 83-88.

*Visser, I. N., Berghan, J., van Meurs, R. \& Fertl, D. (2000). Killer whale (Orcinus orca) predation on a shortfin mako shark (Isurus oxyrinchus) in New Zealand waters. Aquatic Mammals 26, 229-231.

*Vrezec, A. \& Tome, D. (2004). Altitudinal segregation betwen ural owl Strix uralensis and tawny owl $S$. aluco: evidence for competitive exclusion in raptorial birds. Bird Study 51, 264-269.
*Ward, J. F., MacDonald, D. W. \& Doncaster, C. P. (1997). Responses of foraging hedgehogs to badger odour. Animal Behaviour 53, 709-720.

*Webster, H., McNutt, J. W. \& МсСомв, K. (2010). Eavesdropping and risk assessment between lions, spotted hyenas and African wild dogs. Ethology 116 233-239.

*Webster, H., McNutt, J. W. \& McСomb, K. (2012). African wild dogs as a fugitive species: playback experiments investigate how wild dogs respond to their major competitors. Ethology 118, 147-156.

*White, P. A. \& Boyd, D. K. (1989). A cougar, Felis concolor, kitten killed and eaten by gray wolves, Canis lupus, in Glacier National Park, Montana. Canadian Field-Naturalist 103, 408-409.

*Williams, T. M., Estes, J. A., Doak, D. F. \& Springer, A. M. (2004). Killer appetites: assessing the role of predators in ecological communities. Ecology $\mathbf{8 5}$ 3373-3384.

Wilson, J. B. (1999). Guilds, functional types and ecological groups. Oikos 86, 507-522.

*Wilson, R. R., Blankenship, T. L., Hooten, M. B. \& Shivik, J. A. (2010). Prey-mediated avoidance of an intraguild predator by its intraguild prey. Oecologia 164, 921-929.

*Young, R. P., Davison, J., Trewby, I. D., Wilson, I. D., Delahay, R. J. \& Doncaster, C. P. (2006). Abundance of hedgehogs (Erinaceus europaeus) in relation to the density and distribution of badgers (Meles meles). Fournal of Zoology 269, 349-356.

Zapata, S. G., Travaini, A., Ferreras, P. \& Delibes, M. (2007). Analysis of trophic structure of two carnivore assemblages by means of guild identification. European Journal of Wildlife Research 53, 276-286.

*Zuberogoitia, I., Arroyo, B., O’Donoghue, B., Zabala, J., Martínez, J. A. Martínez, J. E. \& Murphy, S. G. (2012). Standing out from the crowd: are patagial wing tags a potential predator attraction for harriers (Circus spp.)? Journal of Ornithology 153, 985-989.

*Zuberogoitia, I., Martínez, J. E., Martínez, J. A., Zabala, J., Calvo, J. F., Azkona, A. \& PAgÁn, I. (2008a). The dho-gaza and mist net with Eurasian Eagle-Owl (Bubo bubo) lure: effectiveness in capturing thirteen species of European raptors. Fournal of Raptor Research 42, 48-51.

Zuberogoitia, I., Martínez, J. E., Zabala, J., Martínez, J. A., Azkona, A. Castillo, I. \& Hidalgo, S. $(2008 b)$. Social interactions between two owl species sometimes associated with intraguild predation. Ardea 96, 109-113.

*Zuberogoitia, I., Martínez, J. A., Zabala, J. \& Martínez, J. E. (2005). Interspecific aggression and nest-site competition in a European owl community. Fournal of Raptor Research 39, 156-159.

(Received 4 January 2013; revised 24 June 2013; accepted 30 July 2013 ) 